\title{
Ability of different types and doses of tannin extracts to modulate in vitro ruminal biohydrogenation in sheep
}

D. Carreño, G. Hervás, P.G. Toral, A. Belenguer, P. Frutos *

Instituto de Ganadería de Montaña (CSIC-ULE), Finca Marzanas s/n, 24346

Grulleros, León, Spain

* Corresponding author. Tel.: +34 987317 156; fax: +34 987317161.

E-mail address: p.frutos@csic.es (P. Frutos). 


\section{ABSTRACT}

The ability of tannins to interfere with ruminal biohydrogenation $(\mathrm{BH})$ and modulate the fatty acid (FA) profile of ruminant-derived products is highly controversial, which is probably related to the type of tannin and the dosage rate. Therefore, this in vitro study was conducted to analyse the effect of 4 commercial extracts of tannins (from chestnut, oak, quebracho and grape) at 4 doses (20,40, 60 and $80 \mathrm{~g} / \mathrm{kg}$ diet DM) with the aim of selecting an effective treatment to modulate the $\mathrm{BH}$ of unsaturated FA. Two in vitro assays with batch cultures of rumen microorganisms, using cannulated ewes as donors of rumen inocula, were performed. The incubated substrate (a total mixed ration similar to that fed to the animals) was supplemented with $20 \mathrm{~g}$ of sunflower oil $/ \mathrm{kg}$ DM. The first experiment followed a $4 \times 4+1$ design (i.e., 4 types of tannins $\times 4$ doses of each one, and a control), and treatment effects on the FA composition of the ruminal digesta were examined by gas chromatography. On the basis of these results, the second experiment was conducted to make sure that the selected dose and type of tannin would not impair rumen fermentation. To this end, gas production kinetic parameters, extent of degradation, in vitro true substrate digestibility, $\mathrm{pH}$, and ammonia and volatile FA concentrations, as well as the bacterial community (by terminal restriction fragment length polymorphism, T-RFLP) were examined. All tannin extracts were able to modulate the in vitro $\mathrm{BH}$ of unsaturated FA. However, the high dose required in many cases suggests that their efficacy would be rather limited in terms of animal feeding. On the other hand, the oak tannin extract, at a dose of $20 \mathrm{~g} / \mathrm{kg}$ diet DM, increased total polyunsaturated FA, 18:3n-3, 18:2n-6 and trans-11 18:1, and decreased trans-10 18:1 and 18:0 rumen concentrations without eliciting any negative response in ruminal fermentation. Although this treatment had no discernible effects on the bacterial community structure and 
diversity, a few fragments compatible with uncultured Lachnospiraceae species were affected.

Keywords: ewe, fatty acid, condensed tannin, hydrolysable tannin, rumen microbiota, ruminal fermentation

Abbreviations: A, cumulative gas production; ADF, acid detergent fibre; AFR, average fermentation rate; aNDF, neutral detergent fibre; BCFA, branched-chain fatty acids; $\mathrm{BH}$, biohydrogenation; $c$, fractional fermentation rate; CHE, chestnut; CLA, conjugated linoleic acid; $\mathrm{CP}$, crude protein; DM, dry matter; DMD, dry matter disappearance; ED, extent of degradation in the rumen; FA, fatty acid; FAME, fatty acid methyl esters; GRA, grape; ivTSD, in vitro true substrate digestibility; OBCFA, odd- and branched-chain fatty acids; OM, organic matter; PUFA, polyunsaturated fatty acids; QUE, quebracho; TMR, total mixed ration; T-RFLP, terminal restriction fragment length polymorphism; VFA, volatile fatty acid. 


\section{Introduction}

Due to consumers' concerns about food of animal origin and demands for healthier food, considerable effort is being made by ruminant nutrition researchers to develop products that are safe and potentially health-promoting. Such properties have been assigned to unsaturated fatty acids (FA) and particularly to conjugated linoleic acids (CLA) formed in the rumen by microbial biohydrogenation $(\mathrm{BH})$ of certain polyunsaturated FA (PUFA; Lock and Bauman., 2004; Shingfield et al., 2008).

Increased levels of desirable FA in ruminant derived products can be achieved through feeding strategies reducing the extent of $\mathrm{BH}$ or facilitating a higher rumen output of cis-9 trans-11 CLA, the main health-promoting CLA isomer, and especially trans-11 18:1, which will act as a precursor of the former in the animal's own tissues (Lock and Bauman, 2004; Shingfield et al., 2008).

Tannins are plant secondary compounds with antibacterial and rumen modulating properties that are able to interfere with BH (McSweeney et al., 2001; Mueller-Harvey, 2006; Vasta et al., 2009a). Some in vitro studies have suggested that diet supplementation with these phenolic compounds may be an efficient tool to favourably modify the BH of dietary PUFA and enhance the accumulation of trans-11 18:1 due to an inhibition of the last step of BH (Khiaosa-ard et al., 2009; Buccioni et al., 2011). However, some others have reported a general inhibition of $\mathrm{BH}$ rather than a specific inhibition of the conversion of trans-11 18:1 to 18:0 (Kronberg et al., 2007; Minieri et al., 2014). In any case, this beneficial effect has rarely been validated in vivo (Vasta et al., 2009b; Khiaosa-ard et al., 2011) and many experiments seem to point to a different direction (e.g., Benchaar and Chouinard, 2009; Cabiddu et al., 2009). 
Results from our studies with lactating ewes fed diets supplemented with a combination of tannin extracts of quebracho and chestnut $(10 \mathrm{~g} / \mathrm{kg}$ diet DM; Toral et al., 2011) or just quebracho (20 g/kg diet DM; Toral et al., 2013) showed that tannin addition was not able to modify milk FA composition towards a potentially healthier profile, especially in the long-term. Recently, Buccioni et al. (2015), using the same tannin extracts (i.e., quebracho and chestnut) but at higher levels (53 g/kg diet DM), observed a slight increase in the milk concentration of linoleic, vaccenic and rumenic acids and a decrease in stearic and saturated FA.

Given the great variation in the structural features and reactivity of different tannins (Álvarez del Pino et al., 2005; Mueller-Harvey, 2006), all these inconsistent results may be attributable to the type and/or concentration of tannins. Thus, there is a void of knowledge about which of the many types of tannins might be potentially more useful for a particular purpose, and also a need for further studies.

Therefore, this in vitro study was conducted to analyse the effect of different types and doses of tannins with the aim of selecting an effective treatment to modulate the ruminal $\mathrm{BH}$ of unsaturated FA. Once a type of tannin at a practical dose (in terms of cost and avoidance of toxicity; Makkar, 2003) was chosen, a secondary aim, before recommending its test in vivo, was to make sure that it would not impair ruminal fermentation.

\section{Materials and methods}

An in vitro trial (Experiment 1) was conducted in batch cultures to assess the effects of different concentrations of a range of tannins on rumen $\mathrm{BH}$. On the basis of the results obtained in this assay, a new in vitro trial (Experiment 2) was conducted to test the effect of a selected type and dose of tannin on rumen fermentation and 
bacterial community. All experimental procedures were approved and completed in accordance with the Spanish Royal Decree 53/2013 for the protection of animals used for experimental purposes.

\subsection{Animals, diet and tannins}

In vitro incubations were conducted as outlined previously (Frutos et al., 2004) with rumen fluid collected from 5 ruminally cannulated (40 $\mathrm{mm}$ internal diameter) Merino sheep (body weight $=63.6 \pm 6.42$ ). All the animals were offered a total mixed ration (TMR, forage:concentrate ratio 50:50), based on alfalfa hay (particle size $>4 \mathrm{~cm}$ ) and concentrates, in two meals $(60 \%$ at 9:00 h and $40 \%$ at 17:00 h) at approximately 0.8 times the voluntary feed intake previously determined $a d$ libitum (37 $\mathrm{g}$ DM/kg metabolic weight and day). Formulation and chemical composition of the diet is shown in Table 1. Animals had continuous access to clean drinking water.

Four types of commercial oenological tannin extracts (Agrovin S.A., Alcázar de San Juan, Spain) were tested: 2 condensed [quebracho (QUE; Schinopsis lorentzii - TanicolMOX) and grape (GRA; Vitis vinifera - Tanicol VMax)] and 2 hydrolysable [chestnut (CHE; Castanea sativa - Vinitanon) and oak (OAK; Quercus robur and Q. petraea - Robletan FST)] tannins.

\subsection{In vitro experiments}

In each experiment, and after an adaptation period of 15 days, rumen fluid inocula (collected in three different days) were obtained via the cannula before the morning feeding. The inocula were immediately taken in thermal flasks to the laboratory where they were strained through a nylon membrane $(400 \mu \mathrm{m}$; Fisher Scientific S.L., Madrid, Spain) while bubbled with $\mathrm{CO}_{2}$.

\subsubsection{Experiment 1}


This trial was conducted using batch cultures of rumen microorganisms (in 16 mL Hungate tubes), following a $4 \times 4+1$ (control) design. Treatments were: 4 types of tannins (quebracho, grape, chestnut and oak) $\times 4$ doses of each one $(20,40,60$ and $80 \mathrm{~g} / \mathrm{kg} \mathrm{DM})$, and a control.

The incubated substrate was a TMR, similar to that used to feed the animals, supplemented with $20 \mathrm{~g}$ of sunflower oil/kg diet DM [Carrefour S.A., Madrid, Spain; containing (g/kg total FA): 16:0 (54.8), 18:0 (44.2), cis-9 18:1 (364) and 18:2n-6 (503)]. Both the oil and the tannins were dissolved, respectively, in ethanol $96 \%$ and in water at about $30^{\circ} \mathrm{C}$, and added into the tubes just before the incubation started.

Each Hungate tube contained $78 \mathrm{mg}$ DM of the substrate (ground using a hammer-mill fitted with a $0.5 \mathrm{~mm}$ screen) that were incubated with $12 \mathrm{~mL}$ of a mix (1:2) of strained rumen fluid and phosphate-bicarbonate buffer (Goering and Van Soest, 1970). The $\mathrm{pH}$ was adjusted to 6.8 with orthophosphoric acid in order to better simulate ruminal conditions in animals fed a 50:50 forage:concentrate diet.

Tubes were incubated under anaerobic conditions for $12 \mathrm{~h}$ (when, according to previous preliminary assays, effects were better detected) in an incubator set at $39.5^{\circ} \mathrm{C}$, and were individually agitated every $6 \mathrm{~h}$. The reaction was stopped by placing the tubes into ice-water for approximately 5-10 $\mathrm{min}$. They were then stored at $-80^{\circ} \mathrm{C}$ until FA analysis.

\subsubsection{Experiment 2}

Once the oak tannin extract at a dose of $20 \mathrm{~g} / \mathrm{kg}$ DM was selected, a new in vitro trial was conducted in $125 \mathrm{~mL}$ sealed serum flasks to test the effect of this treatment on rumen fermentation and bacterial community.

For each of the three runs, two samples of each treatment (i.e., control and OAK20; $325 \mathrm{mg}$ DM milled to pass a $1 \mathrm{~mm}$ screen) and two blanks (i.e., buffered 
rumen fluid without substrate) were incubated at $39.5^{\circ} \mathrm{C}$ with $50 \mathrm{~mL}$ of a mix (1:2) of strained rumen fluid and phosphate-bicarbonate buffer. The $\mathrm{pH}$ of the buffer solution was adjusted to 6.8 as in the Experiment 1.

The rate and extent of gas production were determined by measuring headspace gas pressure at $2,4,6,9,12,16,20,24,30,36,48,60$ and 72 h postinoculation. Pressure values, corrected for the quantity of organic matter (OM) incubated and gas released from blanks, were used to generate gas volume estimates using a predictive equation, as reported in Frutos et al. (2004). Dry matter disappearance (DMD; $\mathrm{g} / \mathrm{kg}$ ) after $72 \mathrm{~h}$ incubation was estimated by filtering residues using pre-weighed sintered glass crucibles (100-160 $\mu$ m; Pyrex, Stone, UK).

In addition, three more flasks per treatment and run were incubated for $24 \mathrm{~h}$. Once the reaction was stopped, the $\mathrm{pH}$ was measured in two flasks and centrifuged samples (at $976 \times g$ for $10 \mathrm{~min}$ ) were collected for ammonia and volatile fatty acid (VFA) analysis. Values of DMD and in vitro true substrate digestibility (ivTSD) were estimated by filtering the residues using pre-weighed sintered glass crucibles (100$160 \mu \mathrm{m}$; Pyrex, Stone, UK) and determining the neutral detergent fibre content, as reported in Frutos et al. (2004). The third flask was immediately frozen at $-80^{\circ} \mathrm{C}$ for subsequent microbial DNA extraction and terminal restriction fragment length polymorphism (T-RFLP) analysis.

\subsection{Chemical analysis}

Feed samples were prepared (ISO 6498:2012) and analysed for DM (ISO 6496:1999), ash (ISO 5984:2002), and crude protein (ISO 5983-2:2009). Neutral and

acid detergent fibres (aNDF and ADF) were determined using an Ankom ${ }^{2000}$ fibre analyser (Ankom Technology Methods 13 and 12, respectively; Ankom Technology Corp., Macedon, NY, USA, https://ankom.com/procedures.aspx); the former was 
assayed with sodium sulfite and $\alpha$-amylase, and both were expressed with residual ash. The content of ether extract in the diets was determined by the Ankom Filter Bag Technology (Ankom Technology Method 2; Ankom Technology Corp.). Fatty acid methyl esters (FAME) of lipid in freeze-dried samples of TMR and in the sunflower oil were prepared in a one-step extraction-transesterification procedure, as outlined previously by Shingfield et al. (2003).

Rumen samples for FA composition were freeze-dried directly in the Hungate tubes. The lipids were then extracted using a mixture of hexane and isopropanol (3:2, vol/vol) and converted to FAME by sequential base-acid catalysed transesterification (Toral et al., 2010). Methyl esters were separated and quantified using a gas chromatograph (Agilent 7890A GC System, Santa Clara, CA, USA) equipped with a flame-ionisation detector and a $100-\mathrm{m}$ fused silica capillary column $(0.25 \mathrm{~mm}$ i.d., 0.2- $\mu$ m film thickness; CP-SIL 88, CP7489, Varian Ibérica S.A., Madrid, Spain) and hydrogen as the carrier gas. Total FAME profile in a $2 \mu \mathrm{L}$ sample volume at a split ratio of 1:50 was determined using a temperature gradient programme (Shingfield et al., 2003). Isomers of 18:1 were further resolved in a separate analysis under isothermal conditions at $170^{\circ} \mathrm{C}$ (Shingfield et al., 2003). Peaks were identified based on retention time comparisons with commercially available authentic standards $(\mathrm{Nu}-$ Chek Prep., Elysian, MN, USA; Sigma-Aldrich, Madrid, Spain; and Larodan Fine Chemicals AB, Malmö, Sweden; Toral et al., 2010), cross referencing with chromatograms reported in the literature (Shingfield et al., 2003; Toral et al., 2010) and comparison with reference samples for which the FA composition was determined based on gas chromatography analysis of FAME and gas chromatography-mass spectrometry analysis of corresponding 4,4-dimethyloxazoline derivatives (Toral et al., 2010). 
The ammonia concentration was determined by colorimetry, and VFA by gas chromatography, using crotonic acid as the internal standard, both in centrifuged samples (Frutos et al., 2004).

\subsection{DNA extraction and T-RFLP analysis}

Frozen samples were freeze-dried and thoroughly mixed before DNA extraction, which was conducted in duplicate using the Qiagen QIAmp DNA Stool Mini Kit (Qiagen Inc., Valencia, CA, USA), with the modification of a greater temperature $\left(95^{\circ} \mathrm{C}\right)$ to improve cell lysis. Duplicate samples were combined and used as templates for T-RFLP analysis of bacterial $16 \mathrm{~S}$ rRNA genes, which were performed as described previously (Castro-Carrera et al., 2014), using three restriction enzymes (HhaI, MspI and HaeIII). Determination of the sizes of the terminal restriction fragments (T-RF) was completed with the size standard ET 900-R (GE Healthcare Life Sciences, Buckinghamshire, UK) and the GeneMarker Analysis software (SoftGenetics, State College, PA, USA). In order to infer the bacterial composition of the samples, in silico restriction for the major rumen bacteria with the primers and the enzymes used were obtained from the Ribosomal Database Project II website (http://rdp.cme.msu.edu/index.jsp; Cole et al., 2014).

\subsection{Calculations and statistical analysis}

Gas production data were fitted to an exponential model using SAS software package (version 9.3, SAS Institute Inc., Cary, NC, USA) to provide parameters describing gas release in terms of cumulative gas production $(A, \mathrm{~mL}$ of gas/g of $\mathrm{OM}$ incubated) and fractional fermentation rate $(c, / \mathrm{h})$. Average fermentation rate (AFR, $\mathrm{mL}$ of gas $/ \mathrm{h}$ ) and extent of degradation in the rumen $(\mathrm{ED}, \mathrm{g} / \mathrm{kg}$ of $\mathrm{DM})$ were estimated assuming a rumen particulate outflow $\left(k_{\mathrm{p}}, / \mathrm{h}\right)$ of 0.042 , according to the 
following equations: $\mathrm{ED}=(c \times \mathrm{DMD}) /\left(c+k_{\mathrm{p}}\right)$, and $\mathrm{AFR}=(A \times c) /(2 \times \ln 2)$, where $\mathrm{DMD}=$ in vitro $\mathrm{DM}$ disappearance after $72 \mathrm{~h}$ of incubation.

Data from T-RFLP (size, bp, and peak area for each T-RF) were analysed for peak filtering and binning as outlined by Abdo et al. (2006), and used to determine the relative abundance of each fragment over the total peak area, as well as the diversity indices (number of T-RF or richness, and Shannon index; Hill et al., 2003). Multivariate analysis of variance (MANOVA) of the relative abundance data of each T-RF was conducted, using the R-project software (www.r-project.org, version 3.1.1), to assess the effect of experimental treatment on the whole bacterial structure.

FA composition of ruminal digesta from the Experiment 1 was analysed by a one-way ANOVA using the MIXED procedure of SAS with a model that included the fixed effect of experimental treatment. Run nested within treatment was designated as the random effect. Orthogonal polynomial contrasts were used to evaluate linear (L), quadratic (Q) and cubic (C) components of the response to incremental amounts of each tannin extract. Rumen fermentation data from the Experiment 2 were analysed using the MIXED procedure of SAS with a model that included the fixed effect of experimental treatment and the random effect of run nested within the treatment. Relative abundances of each T-RF were analysed similarly, although some data did not satisfy the assumptions of normality and were transformed to $\log _{10}(n+c)$ ("c" being a constant of the same order of magnitude as the variable). Differences were declared significant at $\mathrm{P}<0.05$ and considered a trend towards significance at $\mathrm{P}<0.10$. Means were separated through the "pdiff" option of the "lsmeans" statement of the MIXED procedure, and least square means are reported.

\section{Results}




\subsection{FA composition of ruminal digesta (Experiment 1)}

As shown in Table 2 and Figure 1, all tannins and doses, with the exception of QUE80, proved to be able to slightly reduce the concentration of 18:0 $(\mathrm{P}<0.001)$ after $12 \mathrm{~h}$ incubations. Low and moderate doses increased concentrations of 18:2n-6 and 18:3n-3 (up to 90 and 86\%, respectively; $\mathrm{P}<0.01$ ). However, only some doses of 60 and $80 \mathrm{~g} / \mathrm{kg}$ tended to augment cis-9 18:1. Likewise, concentrations of cis-9 trans-11 18:2 were only favoured by $60 \mathrm{~g} / \mathrm{kg}$ of QUE and CHE, and 80 of GRA and OAK $(\mathrm{P}<0.001)$, the highest value representing an increase of $128 \%$ compared to the control. No significant effect of the tannin treatment was observed on the digesta concentration of trans-9 cis-12 18:2.

A tendency to a greater accumulation of trans-11 18:1 was only detected with 60 and $80 \mathrm{~g} / \mathrm{kg}$ of GRA and CHE, and 20 of OAK (up to $16 \% ; \mathrm{P}<0.10$ ). The concentration of trans-10 18:1 showed an irregular behaviour: although QUE60 increased it, most other treatments (e.g., QUE, CHE and OAK at $20 \mathrm{~g} / \mathrm{kg}$ ) decreased it $(\mathrm{P}<0.001)$.

These variations were accompanied by a number of changes in several odd and branched-chain FA and also in some oxo-FA concentrations (see Table 3 and Figure 1). Thus, the proportion of 14:0 iso was increased by QUE and CHE at 20, 40 and $60 \mathrm{~g} / \mathrm{kg}$ and by $\mathrm{OAK}$ at 20 and $40 \mathrm{~g} / \mathrm{kg}(\mathrm{P}<0.01)$. No differences were found in 15:0 iso $(\mathrm{P}>0.10)$ while many treatments increased 15:0 anteiso, and 15:0 was higher in QUE40 and CHE20 and $40(\mathrm{P}<0.05)$. All tannins decreased 17:0 when added at doses of 20, 40 and $60 \mathrm{~g} / \mathrm{kg}$, and GRA and CHE also at $80 \mathrm{~g} / \mathrm{kg}$. Overall, despite the

erratic pattern, all tannin extracts led to general increases in both branched-chain (BCFA) and odd- and branched-chain (OBCFA) fatty acids $(\mathrm{P}<0.01)$.

\subsection{Rumen fermentation and bacterial community (Experiment 2)}


As shown in Table 4, addition of OAK20 had no effect on any of the rumen fermentation characteristics that were analysed (e.g., gas production kinetic parameters, extent of degradation, $\mathrm{pH}$, ammonia and VFA concentrations, molar proportions of VFA, etc.; $\mathrm{P}>0.10)$.

Regarding the microbiota, MANOVA revealed that OAK20 had no discernible effects on the bacterial community structure $(\mathrm{P}>0.10)$. Neither did the diversity indices (richness and Shannon) differ between treatments in data derived from the enzymes HhaI, MspI and HaeIII (P>0.10; Table 5). However, the OAK20 induced variations in the relative abundances of a few T-RF (Table 5), such as an increase in some fragments that may correspond to uncultured bacteria of the class Clostridia (750 bp with HhaI; $\mathrm{P}<0.10$ ) or the family Lachnospiraceae (65 bp with HhaI, 293 bp with MspI, and 277 bp with HaeIII; P<0.05).

\section{Discussion}

Due to its major influence on the FA composition of ruminant meat and milk, a great deal of effort has been directed towards modulation of lipid metabolism in the rumen (Lock and Bauman, 2004; Shingfield et al., 2008). The ability of tannins to contribute to this goal is highly controversial, which is most probably related to their type and dosage rate, and highlights the need to further investigate on this issue.

As shown in Figure 1, although most FA concentrations follow a similar pattern of response to tannin extracts (e.g., decreases in 17:0 and 18:0 or increases in 18:2n-6 and 18:3n-3), there were also many exceptions in their effects (e.g., on trans10 and trans-11 18:1 or on cis-9 trans-11 18:2) due to both the type of tannin and the dose. 
Starting from the type, there are some studies on the use of commercial extracts of quebracho, and also of chestnut tannins (e.g., Vasta et al., 2009a; Toral et al., 2011; Buccioni et al., 2015), although their results are rather inconsistent. Nevertheless, and despite some works have been conducted with grape seeds (e.g., Correddu et al., 2015), reports are very limited for marketable extracts of grape or oak tannins.

Tannins comprise a very wide and heterogeneous group of phenolic compounds with different chemical and structural features (Mueller-Harvey, 2006). Hence, dissimilarities in procyanidin/prodelphinidin ratios, degree of galloylation, molecular weights, etc. would account for major variations in their ability to bind to other molecules or to affect microorganisms, and consequently in their effects, in this case on ruminal $\mathrm{BH}$. In line with this, for example, the inclusion of an extract of condensed tannins from Acacia mearnsii (79 $\mathrm{g} / \mathrm{kg} \mathrm{DM}$ ) inhibited the in vitro conversion of trans-11 18:1 to 18:0, while the same amount of tannins from Onobrychis viciifolia decreased the hydrogenation of linoleic and linolenic acids but had no effect on the last step of BH (Khiaosa-ard et al., 2009).

Regarding the key issue of the dosage rate, we chose 4 doses to have a wide range that allow us to detect effects that may help to understand the underlying mechanisms of tannins. However, only the low $(20 \mathrm{~g} / \mathrm{kg})$ and perhaps the moderate $(40 \mathrm{~g} / \mathrm{kg}$ ) concentrations might be of interest in terms of animal feeding. Even if the 60 and $80 \mathrm{~g} / \mathrm{kg}$ doses had shown promising effects on the BH process, they could be not only detrimental to animal performance but also impractical under farm conditions due to their cost. This occurs, for instance, in some in vitro assays that found a beneficial impact of tannins on BH but at very high levels (up to $160 \mathrm{~g} / \mathrm{kg}$ DM; Vasta et al., 2009a). The difficulty in selecting dosage rates of plant secondary 
compounds to positively affect a particular parameter without conferring a negative response in others has been previously reported in several occasions (e.g., Benchaar et al., 2008; Toral et al., 2013).

In any case, regardless of the practicality, our results do not clearly point to a greater ability of a particular dose to modulate the $\mathrm{BH}$ process towards a potentially healthier FA profile, suggesting interactions between types of tannins, doses and specific steps of the BH pathways. Thus, for example, only doses of 60 and $80 \mathrm{~g} / \mathrm{kg}$ were able to promote the accumulation of cis-9 trans-11 CLA, while those of 20, 40 and $60 \mathrm{~g} / \mathrm{kg}$ increased the concentration of total PUFA, linoleic and linolenic acids, and QUE80 was the only treatment unable to decrease the proportion of 18:0. In agreement with this, Buccioni et al. (2011) observed that the effect of tannins on the $\mathrm{BH}$ process was, in many cases, stronger with a lower dose (49 vs. $82 \mathrm{~g} / \mathrm{kg} \mathrm{DM}$ ).

Overall, our results are consistent with those of other in vitro studies (e.g., Kronberg et al., 2007; Minieri et al., 2014) and suggest a general inhibition of the BH rather than the specific negative effect on the conversion of trans-11 18:1 to 18:0 that had been detected in some in vitro assays (Khiaosa-ard et al., 2009, Vasta et al., 2009a, Buccioni et al., 2011). However, as mentioned in the introduction, they are in disagreement with the slight but positive effects reported by Buccioni et al. (2015) in ewes fed quebracho and chestnut tannin extracts at a dose of $53 \mathrm{~g} / \mathrm{kg}$ diet DM. Although differences between in vitro and in vivo results cannot be ruled out, after a comprehensive comparison of these studies, the reason for the discrepancy is still uncertain. It is noteworthy, however, that in this latter work, tannin extracts replaced bentonite from the diet, which might partly explain some differences with the control diet, due to the potential effects of this clay on BH (Jeronimo et al., 2010). 
Despite all tannin extracts tended to favour a slight accumulation of trans-11 18:1 (with a $\mathrm{P}<0.10$ only with doses of 60 and $80 \mathrm{~g} / \mathrm{kg}$ of grape and chestnut, and 20 of oak), their effect on the concentration of trans-10 18:1, a FA with an uncertain involvement in consumers' health and animals' performance (Shingfield et al., 2008), was highly variable. This is in line with inconsistent results found in the literature (e.g., Cabiddu et al., 2009, Abbedou et al., 2011; Toral et al., 2011). Nevertheless, the formation of trans-10 18:1 was not promoted at the expense of trans-11 18:1, which may be related to the basal diet (Vasta et al., 2009b) and would indicate only small deviations from major ruminal $\mathrm{BH}$ pathways.

In this regard, concentrations of trans-9 cis-12 18:2 were investigated to test the hypothesis that tannins would benefit microbial populations able to metabolise cis-9 cis-12 18:2 via mechanisms other than isomerisation of the cis-12 double bond. However, this minor BH pathway (Honkanen et al., 2012), observed in sheep fed quebracho tannins (Toral et al., 2013), was not evident in our current assay.

Different effects of the extracts on the $\mathrm{BH}$ of different unsaturated FA would suggest a distinct sensitivity to tannins of the microorganisms involved in each step of the process (Buccioni et al., 2011) because all changes are supposed to be mediated by the impact of tannins on the microbiota. This was supported by the variations observed in odd- and branched-chain FA, which are known to be largely derived from bacteria (Fievez et al., 2012). The quoted review by Fievez et al. (2012) related an increased proportion of cellulolytic bacteria with a high iso FA content, while increased amylolytic populations would facilitate a higher content of anteiso and linear odd-chain FA. Yet, the erratic pattern observed in our incubations does not allow us to attribute differences to specific alterations in these two kinds of bacteria. Changes in odd- and branched-chain FA reflecting shifts in rumen microorganisms 
are also supported by variations in some keto-FA (e.g., 10-oxo- and 13-oxo-18:0), which suggest alteration of the ruminal pathways (Toral et al., 2010, 2012).

To recapitulate, the treatment showing a more promising behaviour at a practical dose was OAK20, which increased total PUFA, 18:3n-3, 18:2n-6 and trans11 18:1, and decreased trans-10 18:1 and 18:0 concentrations. Therefore, the second experiment was conducted to ensure that this oenological extract of hydrolysable tannins would not elicit a negative response in ruminal fermentation.

Although the attribution of more toxic and less efficient results to hydrolysable than to condensed tannins has proved simplistic and erroneous, some generalisations still persist (Mueller-Harvey, 2006). However, the OAK20 modulated BH but did not detrimentally affect any of the rumen fermentation characteristics that were analysed, most likely due to the small amount added to the diet. A number of studies have demonstrated this dose-dependent effect of tannins (e.g., Hervás et al., 2003, Makkar, 2003), which is even applicable to their capacity to reduce rumen ammonia concentration due to their strong inhibitory effect on proteolysis (Makkar, 2003; Frutos et al., 2004; Mueller-Harvey, 2006).

Finally, regarding the microbial analyses, the low dose of tannins precluded major changes and therefore discernible effects were observed neither in the bacterial community structure nor in the diversity indices. Furthermore, the issue of the shifts in specific bacteria involved in $\mathrm{BH}$ is rather complicated because recent studies question previous reports indicating that $\mathrm{BH}$ is achieved only by a small group of bacteria and suggest that yet uncultivated species would play a relevant role (Huws et al., 2011; Toral et al., 2012, Castro-Carrera et al., 2014).

In this assay, some T-RF affected by the addition of OAK20 are compatible with uncultured species belonging to the family Lachnospiraceae, which include 
bacterial strains that have been related to lipid metabolism, both in vitro (Paillard et al., 2007; Boeckaert et al., 2009) and in vivo (Huws et al., 2011; Toral et al., 2012). Concerning the tolerance of the microbes of this diverse group to the presence of tannins, reports in the literature are once again inconsistent. For example, it has been reported that sainfoin (Onobrychis viciifolia) tannins inhibit the growth of a strain of Butyrivibrio fibrisolvens in vitro (Jones et al., 1994) but tannin-resistant bacteria of this genus have been identified in the rumen (Odenyo et al., 2001). Indeed, Vasta et al. (2010) observed in lambs that the addition of quebracho tannins to the diet increased its abundance.

\section{Conclusions}

The four oenological tannin extracts (quebracho, grape, chestnut and oak) that were examined in this study seem to be able to modulate the in vitro $\mathrm{BH}$ of unsaturated FA. However, the high dose required in many cases suggests that their efficacy would be rather limited in terms of animal feeding. On the other hand, the oak tannin extract, at a practical dose of $20 \mathrm{~g} / \mathrm{kg}$ diet DM, increases total PUFA, 18:3n-3, 18:2n-6 and trans-11 18:1, and decreases trans-10 18:1 and 18:0 rumen concentrations without eliciting any negative response in ruminal fermentation. Further studies would be now necessary to examine if these positive effects are extended to in vivo conditions.

\section{Conflict of interest}

No conflict of interest.

\section{Acknowledgments}


D. Carreño and P. G. Toral gratefully acknowledge receipt of an FPI predoctoral grant and a Juan de la Cierva research contract, respectively, from the Spanish Ministry of Economy and Competitiveness (MINECO). The authors thank Dr

L. Barrios (Biostatistics Department, CSIC; Madrid, Spain) for helpful assistance with statistical analysis. This work was supported by the MINECO (AGL2011-23700).

\section{References}

Abbeddou, S., Rischkowsky, B., Richter, E.K., Hess, H.D., Kreuzer, M., 2011. Modification of milk fatty acid composition by feeding forages and agroindustrial byproducts from dry areas to Awassi sheep. J. Dairy Sci. 94, 4657-4668.

Abdo, Z., Schüette, U.M.E., Bent, S.J., Williams, C.J., Forney, L.J., Joyce, P., 2006. Statistical methods for characterizing diversity of microbial communities by analysis of terminal restriction fragment length polymorphisms of $16 \mathrm{~S}$ rRNA genes. Environ. Microbiol. 8, 929-938.

Álvarez del Pino, M.C., Hervás, G., Mantecón, A.R., Giráldez, F.J., Frutos, P., 2005. Comparison of biological and chemical methods, and internal and external standards, for assaying tannins in Spanish shrub species. J. Sci. Food Agric. 85, $583-590$.

Benchaar, C., Chouinard, P.Y., 2009. Assessment of the potential of cinnamaldehyde, condensed tannins, and saponins to modify milk fatty acid composition of dairy cows. J. Dairy Sci. 92, 3392-3396.

Benchaar, C., McAllister, T.A., Chouinard, P.Y., 2008. Digestion, ruminal fermentation, ciliate protozoal populations, and milk production from dairy cows fed cinnamaldehyde, quebracho condensed tannin, or Yucca schidigera 
saponin extracts. J. Dairy Sci. 91, 4765-4777.

Boeckaert, C., Morgavi, D.P., Jouany, J.P., Maignien, L., Boon, N., Fievez, V., 2009. Role of the protozoan Isotricha prostoma, liquid-, and solid-associated bacteria in rumen biohydrogenation of linoleic acid. Animal 3, 961-971.

Buccioni, A., Minieri, S., Rapaccini, S., Antongiovanni, M., Mele, M., 2011. Effect of chestnut and quebracho tannins on fatty acid profile in rumen liquid- and solidassociated bacteria: an in vitro study. Animal 5, 1521-1530.

Buccioni, A., Pauselli, M., Viti, C., Minieri, S., Pallara, G., Roscini, V., Rapaccini, S., Trabalza Marinucci, M.T., Lupi, P., Conte, G., Mele, M., 2015. Milk fatty acid composition, rumen microbial population, and animal performances in response to diets rich in linoleic acid supplemented with chestnut or quebracho tannins in dairy ewes. J. Dairy Sci. 98, 1145-1156.

Cabiddu, A., Molle, G., Decandia, M., Spada, S., Fiori, M., Piredda, G., Addis, M., 2009. Responses to condensed tannins of flowering sulla (Hedysarum coronarium L.) grazed by dairy sheep. Part 2: Effects on milk fatty acid profile. Livest. Sci. 123, 230-240.

Castro-Carrera, T., Toral, P.G., Frutos, P., McEwan, N.R., Hervás, G., Abecia, L., Pinloche, E., Girdwood, S.E., Belenguer, A., 2014. Rumen bacterial community evaluated by 454 pyrosequencing and terminal restriction fragment length polymorphism analyses in dairy sheep fed marine algae. J. Dairy Sci. 97, $1661-1669$.

Cole, J.R., Wang, Q., Fish, J., Chai, B., McGarrell, D.M., Sun, Y., Titus Brown, C., Porras-Alfaro, A., Kuske, C.A., Tiedje, J.M., 2014. Ribosomal Database Project: data and tools for high throughput rRNA analysis. Nucleic Acids Res. 42, D633-D642. 
Correddu, F., Nudda, A., Battacone, G., Boe, R., Francesconi, A.H.D., Pulina, G., 2015. Effects of grape seed supplementation, alone or associated with linseed, on ruminal metabolism in Sarda dairy sheep. Anim. Feed Sci. Technol. 199, $61-72$.

Fievez, V., Colman, E., Castro-Montoya, J.M., Stefanov, I., Vlaeminck, B., 2012. Milk odd- and branched-chain fatty acids as biomarkers of rumen function - An update. Anim. Feed Sci. Technol. 172, 51-65.

Frutos, P., Hervás, G., Giráldez, F.J., Mantecón, A.R., 2004. An in vitro study on the ability of polyethylene glycol to inhibit the effect of quebracho tannins and tannic acid on rumen fermentation in sheep, goats, cows, and deer. Aust. J. Agric. Res. 55, 1125-1132.

Goering, M.K., Van Soest, P.J., 1970. Forage Fiber Analysis (Apparatus, Reagents, Procedures and some Applications). Agriculture Handbook, No 379. Agricultural Research Service, USDA, Washington, USA.

Hervás, G., Frutos, P., Giráldez, F.J., Mantecón, A.R., Álvarez del Pino, M.C., 2003. Effect of different doses of quebracho tannins extract on rumen fermentation in ewes. Anim. Feed Sci. Technol. 109, 65-78.

Hill, T.C.J., Walsh, K.A., Harris, J.A., Moffett, B.F., 2003. Using ecological diversity measures with bacterial communities. FEMS Microbiol. Ecol. 43, 1-11.

Honkanen, A.M., Griinari, J.M., Vanhatalo, A., Ahvenjärvi, S., Toivonen, V., Shingfield, K.J., 2012. Characterization of the disappearance and formation of biohydrogenation intermediates during incubations of linoleic acid with rumen fluid in vitro. J. Dairy Sci. 95, 1376-1394.

Huws, S.A., Kim, E.J., Lee, M.R.F., Scott, M.B., Tweed, J.K.S., Pinloche, E., Wallace, R.J., Scollan, N.D., 2011. As yet uncultured bacteria phylogenetically 
classified as Prevotella, Lachnospiraceae incertae sedis and unclassified Bacteroidales, Clostridiales and Ruminococcaceae may play a predominant role in ruminal biohydrogenation. Environ. Microbiol. 13, 1500-1512.

Jeronimo, E., Alves, S.P., Martins, S.V., Prates, J.A.M., Bessa, R.J.B., Santos-Silva, J., 2010. Effect of sodium bentonite and vegetable oil blend supplementation on growth, carcass quality and intramuscular fatty acid composition of lambs. Anim. Feed Sci. Technol. 158, 136-145.

Jones, G.A., McAllister, T.A., Muir, A.D., Cheng, K.-J., 1994. Effects of sainfoin (Onobrychis viciifolia Scop) condensed tannins on growth and proteolysis by 4 strains of ruminal bacteria. Appl. Environ. Microbiol. 60, 1374-1378.

Khiaosa-ard, R., Bryner, S.F., Scheeder, M.R.L., Wettstein, H.R., Leiber, F., Kreuzer, M., Soliva, C.R., 2009. Evidence for the inhibition of the terminal step of ruminal alpha-linolenic acid biohydrogenation by condensed tannins. J. Dairy Sci. 92, 177-188.

Khiaosa-ard, R., Soliva, C.R., Kreuzer, M., Leiber, F., 2011. Influence of alpine forage either employed as donor cow's feed or as incubation substrate on in vitro ruminal fatty acid biohydrogenation. Livest. Sci. 140, 80-87.

Kronberg, S.L., Scholljegerdes, E.J., Barcelo-Coblijn, G., Murphy, E.J., 2007. Flaxseed treatments to reduce biohydrogenation of alpha-linolenic acid by rumen microbes in cattle. Lipids 42, 1105-1111.

Lock, A.L., Bauman, D.E., 2004. Modifying milk fat composition of dairy cows to enhance fatty acids beneficial to human health. Lipids 39, 1197-1206.

Makkar, H.P.S., 2003. Effects and fate of tannins in ruminant animals, adaptation to tannins, and strategies to overcome detrimental effects of feeding tannin-rich feeds. Small Rumin. Res. 49, 241-256. 
McSweeney, C.S., Palmer, B., McNeill, D.M., Krause, D.O., 2001. Microbial interactions with tannins: nutritional consequences for ruminants. Anim. Feed Sci. Technol. 91, 83-93.

Minieri, S., Buccioni, A., Rapaccini, S., Pezzati, A., Benvenuti, D., Serra, A., Mele, M., 2014. Effect of quebracho tannin extract on soybean and linseed oil biohydrogenation by solid associated bacteria: an in vitro study. Ital. J. Anim. Sci. 13, 604-608.

Mueller-Harvey, I., 2006. Unravelling the conundrum of tannins in animal nutrition and health. J. Sci. Food Agric. 86, 2010-2037.

Odenyo, A.A., Bishop, R., Asefa, G., Jamnadass, R., Odongo, D., Osuji, P., 2001. Characterization of tannin-tolerant bacterial isolates from East African ruminants. Anaerobe 7, 5-15.

Paillard, D., McKain, N., Chaudhary, L.C., Walker, N.D., Pizette, F., Koppova, I., McEwan, N.R., Kopecny, J., Vercoe, P.E., Louis, P., Wallace, R.J., 2007. Relation between phylogenetic position, lipid metabolism and butyrate production by different Butyrivibrio-like bacteria from the rumen. Anton. Leeuw. Int. J. G. 91, 417-422.

Shingfield, K.J., Ahvenjärvi, S., Toivonen, V., Äröla, A., Nurmela, K.V.V., Huhtanen, P., Griinari. J.M., 2003. Effect of dietary fish oil on biohydrogenation of fatty acids and milk fatty acid content in cows. Anim. Sci. $77,165-179$.

Shingfield, K.J., Chilliard, Y., Toivonen, V., Kairenius, P., Givens, D.I., 2008. Trans fatty acids and bioactive lipids in ruminant milk. Adv. Exp. Med. Biol. 606, $3-65$. 
Toral, P.G., Belenguer, A., Shingfield, K.J., Hervás, G., Toivonen, V., Frutos, P., 2012. Fatty acid composition and bacterial community changes in the rumen fluid of lactating sheep fed sunflower oil plus incremental levels of marine algae. J. Dairy Sci. 95, 794-806.

Toral, P.G., Hervás, G., Belenguer, A., Bichi, E., Frutos, P., 2013. Effect of the inclusion of quebracho tannins in a diet rich in linoleic acid on milk fatty acid composition in dairy ewes. J. Dairy Sci. 96, 431-439.

Toral, P.G., Hervás, G., Bichi, E., Belenguer, A., Frutos, P., 2011. Tannins as feed additives to modulate ruminal biohydrogenation: Effects on animal performance, milk fatty acid composition and ruminal fermentation in dairy ewes fed a diet containing sunflower oil. Anim. Feed Sci. Technol. 164, 199-206.

Toral, P.G., Shingfield, K.J., Hervás, G., Toivonen, V., Frutos, P., 2010. Effect of fish oil and sunflower oil on rumen fermentation characteristics and fatty acid composition of digesta in ewes fed a high concentrate diet. J. Dairy Sci. 93, 4804-4817.

Vasta, V., Makkar, H.P.S., Mele, M., Priolo, A., 2009a. Ruminal biohydrogenation as affected by tannins in vitro. Br. J. Nutr. 102, 82-92.

Vasta, V., Mele, M., Serra, A., Scerra, M., Luciano, G., Lanza, M., Priolo, A., 2009b. Metabolic fate of fatty acids involved in ruminal biohydrogenation in sheep fed concentrate or herbage with or without tannins. J. Anim. Sci. 87, 2674-2684.

Vasta, V., Yañez-Ruiz, D.R., Mele, M., Serra, A., Luciano, G., Lanza, M., Biondi, L., Priolo, A., 2010. Bacterial and protozoal communities and fatty acid profile in the rumen of sheep fed a diet containing added tannins. Appl. Environ. Microbiol. 76, 2549-2555. 


\section{Table 1}

Formulation and chemical composition of the experimental diet.

\begin{tabular}{|c|c|c|}
\hline & $\mathrm{TMR}^{1}$ & $\mathrm{SEM}^{2}$ \\
\hline \multicolumn{3}{|l|}{ Ingredients, $\mathrm{g} / \mathrm{kg}$ of fresh matter } \\
\hline Dehydrated alfalfa hay & 500 & - \\
\hline Whole corn grain & 140 & - \\
\hline Whole barley grain & 100 & - \\
\hline Soybean meal solvent $440 \mathrm{~g} \mathrm{CP} / \mathrm{kg}$ & 150 & - \\
\hline Sugar beet pulp, pellets & 50 & - \\
\hline Molasses, liquid & 40 & - \\
\hline Mineral supplement ${ }^{3}$ & 18 & - \\
\hline Vitamin supplement ${ }^{4}$ & 2 & - \\
\hline \multicolumn{3}{|l|}{ Chemical composition, g/kg DM } \\
\hline Organic matter & 900 & 3.15 \\
\hline Crude protein & 187 & 6.08 \\
\hline Neutral detergent fibre & 311 & 24.3 \\
\hline Acid detergent fibre & 218 & 21.1 \\
\hline Ether extract & 23.5 & 1.80 \\
\hline
\end{tabular}

${ }^{1} \mathrm{n}=6$. Contained (g/kg of total fatty acids): 16:0 (252), 18:0 (53.8), cis-9 18:1 (139), 18:2n-6 (346) and 18:3n-3 (119).

${ }^{2} \mathrm{SEM}=$ standard error of the mean.

${ }^{3}$ Contained (g/kg): $\mathrm{CaCO}_{3}$ (556), $\mathrm{Ca}_{2} \mathrm{HPO}_{4}$ (222), and $\mathrm{NaCl}(222)$.

${ }^{4}$ VITAFAC Ovino $0.2 \%$ AC (DSM Nutritional Products S.A., Madrid, Spain).

Declared as containing: vitamin A (4,000,000 IU/kg), vitamin D3 (1,000,000 IU/kg), vitamin E (5 g/kg), iron $(17.5 \mathrm{~g} / \mathrm{kg})$, manganese $(20 \mathrm{~g} / \mathrm{kg})$, cobalt $(50 \mathrm{mg} / \mathrm{kg})$, iodine (250 mg/kg), zinc (15 g/kg), selenium $(100 \mathrm{mg} / \mathrm{kg})$, sepiolite $(100 \mathrm{~g} / \mathrm{kg})$, calcium $(26.2 \mathrm{~g} / \mathrm{kg})$, and magnesium $(6.15 \mathrm{~g} / \mathrm{kg})$. 


\section{Table 2}

Effect of incremental levels of different tannin extracts (quebracho, QUE; grape, GRA; chestnut, CHE; oak, OAK) on 18:0 and unsaturated fatty acid concentration (g/100 g of total fatty acids) after 12-h in vitro incubation with rumen inoculum from sheep ${ }^{1}$.

\begin{tabular}{|c|c|c|c|c|c|c|c|c|c|}
\hline & $18: 0$ & cis-9 18:1 & $\begin{array}{c}\text { trans }-10 \\
18: 1\end{array}$ & trans-11 18:1 & $\begin{array}{c}\text { cis-9 } \\
\text { trans-11 } \\
18: 2^{2}\end{array}$ & $\begin{array}{l}\text { trans-9 cis- } \\
\quad 1218: 2\end{array}$ & $18: 2 n-6$ & $18: 3 n-3$ & $\mathrm{PUFA}^{3}$ \\
\hline Control & $61.2^{\mathrm{a}}$ & $2.06^{\mathrm{c}}$ & $0.387^{\mathrm{b}-\mathrm{e}}$ & $5.15^{\mathrm{d}}$ & $0.088^{\mathrm{d}-\mathrm{f}}$ & 0.033 & $0.877^{\mathrm{f}}$ & $0.175^{\mathrm{f}}$ & $1.38^{\mathrm{e}}$ \\
\hline QUE20 & $58.8^{\mathrm{c}-\mathrm{e}}$ & $2.24^{\mathrm{bc}}$ & $0.354^{\mathrm{f}-\mathrm{h}}$ & $5.35^{\mathrm{cd}}$ & $0.092^{\mathrm{d}-\mathrm{f}}$ & 0.035 & $1.31^{\mathrm{b}-\mathrm{d}}$ & $0.278^{\mathrm{a}-\mathrm{d}}$ & $2.07^{\mathrm{b}-\mathrm{d}}$ \\
\hline QUE40 & $58.2^{\mathrm{ef}}$ & $2.40^{\mathrm{bc}}$ & $0.321^{\mathrm{h}}$ & $5.57^{\mathrm{a}-\mathrm{d}}$ & $0.100^{\mathrm{d}-\mathrm{f}}$ & 0.034 & $1.41^{\mathrm{a}-\mathrm{d}}$ & $0.314^{\mathrm{ab}}$ & $2.21^{\mathrm{ab}}$ \\
\hline QUE60 & $58.7^{\mathrm{de}}$ & $2.45^{\mathrm{ab}}$ & $0.423^{\mathrm{a}}$ & $5.61^{\mathrm{a}-\mathrm{d}}$ & $0.142^{c}$ & 0.036 & $1.42^{\mathrm{a}-\mathrm{d}}$ & $0.286^{\mathrm{a}-\mathrm{c}}$ & $2.21^{\mathrm{ab}}$ \\
\hline QUE80 & $60.4^{\mathrm{ab}}$ & $2.31^{b c}$ & $0.406^{\mathrm{a}-\mathrm{c}}$ & $5.29^{\mathrm{cd}}$ & $0.098^{\mathrm{d}-\mathrm{f}}$ & 0.038 & $1.11^{\mathrm{c}-\mathrm{f}}$ & $0.213^{\mathrm{d}-\mathrm{f}}$ & $1.77^{\mathrm{de}}$ \\
\hline GRA20 & $58.4^{\mathrm{ef}}$ & $2.21^{b c}$ & $0.398^{\mathrm{a}-\mathrm{d}}$ & $5.30^{\mathrm{cd}}$ & $0.081^{\mathrm{d}-\mathrm{f}}$ & 0.038 & $1.31^{\mathrm{b}-\mathrm{d}}$ & $0.285^{\mathrm{a}-\mathrm{c}}$ & $2.07^{\mathrm{b}-\mathrm{d}}$ \\
\hline GRA40 & $58.4^{\mathrm{ef}}$ & $2.29^{\mathrm{bc}}$ & $0.368^{\mathrm{d}-\mathrm{g}}$ & $5.49^{\mathrm{a}-\mathrm{d}}$ & $0.114^{\mathrm{c}-\mathrm{e}}$ & 0.033 & $1.29^{b-d}$ & $0.256^{\mathrm{a}-\mathrm{e}}$ & $2.13^{\mathrm{b}}$ \\
\hline GRA60 & $58.1^{\mathrm{ef}}$ & $2.48^{\mathrm{ab}}$ & $0.393^{\mathrm{a}-\mathrm{e}}$ & $5.68^{\mathrm{a}-\mathrm{c}}$ & $0.091^{\mathrm{d}-\mathrm{f}}$ & 0.042 & $1.27^{\mathrm{b}-\mathrm{e}}$ & $0.234^{\mathrm{c}-\mathrm{f}}$ & $2.21^{\mathrm{ab}}$ \\
\hline GRA80 & $58.9^{\mathrm{c}-\mathrm{e}}$ & $2.60^{\mathrm{a}}$ & $0.400^{\mathrm{a}-\mathrm{d}}$ & $5.95^{\mathrm{a}}$ & $0.201^{\mathrm{a}}$ & 0.037 & $1.14^{\mathrm{b}-\mathrm{f}}$ & $0.230^{\mathrm{c}-\mathrm{f}}$ & $1.86^{\mathrm{b}-\mathrm{d}}$ \\
\hline CHE20 & $58.4^{\mathrm{ef}}$ & $2.28^{\mathrm{bc}}$ & $0.346^{\mathrm{gh}}$ & $5.25^{\mathrm{cd}}$ & $0.096^{\mathrm{d}-\mathrm{f}}$ & 0.030 & $1.47^{\mathrm{ab}}$ & $0.307^{\mathrm{ab}}$ & $2.25^{\mathrm{ab}}$ \\
\hline CHE40 & $58.4^{\mathrm{ef}}$ & $2.34^{\mathrm{a}-\mathrm{c}}$ & $0.354^{\mathrm{f}-\mathrm{h}}$ & $5.38^{\mathrm{b}-\mathrm{d}}$ & $0.100^{\mathrm{d}-\mathrm{f}}$ & 0.033 & $1.47^{\mathrm{ab}}$ & $0.313^{\mathrm{ab}}$ & $2.27^{\mathrm{ab}}$ \\
\hline CHE60 & $57.4^{\mathrm{f}}$ & $2.60^{\mathrm{a}}$ & $0.411^{\mathrm{ab}}$ & $5.71^{\mathrm{a}-\mathrm{c}}$ & $0.186^{\mathrm{ab}}$ & 0.042 & $1.67^{\mathrm{a}}$ & $0.325^{\mathrm{a}}$ & $2.56^{\mathrm{a}}$ \\
\hline CHE80 & $59.8^{b-d}$ & $2.37^{\mathrm{ab}}$ & $0.386^{\mathrm{b}-\mathrm{t}}$ & $5.65^{\mathrm{a}-\mathrm{c}}$ & $0.114^{\mathrm{c}-\mathrm{e}}$ & 0.043 & $1.08^{\mathrm{d}-\mathrm{f}}$ & $0.198^{\mathrm{ef}}$ & $1.74^{\mathrm{c}-\mathrm{e}}$ \\
\hline OAK20 & $58.0^{\text {ef }}$ & $2.34^{\mathrm{abc}}$ & $0.352^{\mathrm{gh}}$ & $5.86^{\mathrm{ab}}$ & $0.076^{\mathrm{ef}}$ & 0.037 & $1.47^{\mathrm{a}-\mathrm{c}}$ & $0.299^{\mathrm{a}-\mathrm{c}}$ & $2.27^{\mathrm{ab}}$ \\
\hline OAK40 & $58.3^{\text {ef }}$ & $2.30^{\mathrm{bc}}$ & $0.376^{\mathrm{c}-\mathrm{g}}$ & $5.59^{a-d}$ & $0.076^{\mathrm{f}}$ & 0.038 & $1.25^{\mathrm{b}-\mathrm{e}}$ & $0.269^{\mathrm{a}-\mathrm{d}}$ & $2.06^{\mathrm{b}-\mathrm{d}}$ \\
\hline OAK60 & $58.5^{\mathrm{ef}}$ & $2.23^{\mathrm{bc}}$ & $0.366^{\mathrm{e}-\mathrm{g}}$ & $5.60^{\mathrm{a}-\mathrm{d}}$ & $0.115^{\mathrm{cd}}$ & 0.032 & $1.29^{\mathrm{b}-\mathrm{d}}$ & $0.247^{\mathrm{b}-\mathrm{e}}$ & $2.11^{\mathrm{bc}}$ \\
\hline OAK80 & $59.9^{\mathrm{bc}}$ & $2.41^{\mathrm{ab}}$ & $0.400^{\mathrm{a}-\mathrm{c}}$ & $5.44^{\mathrm{b}-\mathrm{d}}$ & $0.148^{b c}$ & 0.039 & $0.906^{\mathrm{ef}}$ & $0.193^{\mathrm{ef}}$ & $1.56^{\mathrm{de}}$ \\
\hline $\mathrm{SED}^{4}$ & 0.692 & 0.155 & 0.160 & 0.233 & 0.0210 & 0.0047 & 0.203 & 0.0349 & 0.278 \\
\hline P-value & $<0.001$ & 0.053 & $<0.001$ & 0.099 & $<0.001$ & 0.288 & 0.006 & $<0.001$ & $<0.001$ \\
\hline \multicolumn{10}{|c|}{ Contrasts 5} \\
\hline QUE & LQ & (L) & Q & (L) & $\mathrm{L}$ & & $\mathrm{L}$ & $\mathrm{L}$ & $\mathrm{L}$ \\
\hline
\end{tabular}




\begin{tabular}{|c|c|c|c|c|c|c|c|}
\hline GRA & LQ & (L) & & & $\mathrm{L}$ & $\mathrm{Q}$ & LQ \\
\hline CHE & LQ & (L) & Q & LQ & $\mathrm{L}$ & LQ & $\mathrm{L}$ \\
\hline OAK & LQC & & & $\mathrm{Q}$ & LQC & $\mathrm{Q}$ & LQC \\
\hline
\end{tabular}

${ }^{1}$ The incubated substrate was a TMR (forage:concentrate ratio 50:50) supplemented with $20 \mathrm{~g}$ of sunflower oil/kg diet DM.

${ }^{2}$ Coelutes with trans-7 cis-9 18:2 and trans-8 cis-10 18:2.

${ }^{3}$ PUFA, polyunsaturated fatty acids.

${ }^{4} \mathrm{SED}=$ standard error of the difference.

${ }^{5}$ For each tannin, significance $(\mathrm{P}<0.05)$ of linear $(\mathrm{L})$, quadratic $(\mathrm{Q})$ and cubic $(\mathrm{C})$ responses to tannin addition. Trends towards significance $(\mathrm{P}<0.10)$ are reported in parentheses.

${ }^{\mathrm{a}-\mathrm{h}}$ Within a column, different superscripts indicate significant differences. 
Table 3

Effect of incremental levels of different tannin extracts (quebracho, QUE; grape, GRA; chestnut, CHE; oak, OAK) on odd- and branched-chain and oxo- fatty acid concentration (g/100 $\mathrm{g}$ of total fatty acids) after 12-h in vitro incubation with rumen inoculum from sheep ${ }^{1}$.

\begin{tabular}{|c|c|c|c|c|c|c|c|c|c|}
\hline & $14: 0$ iso & $15: 0$ iso & 15:0 anteiso & $15: 0$ & $17: 0$ & $\mathrm{BCFA}^{2}$ & $\mathrm{OBCFA}^{3}$ & 10-охо-18:0 & 13-охо-18:0 \\
\hline Control & $0.068^{\mathrm{e}}$ & 0.261 & $0.431^{\mathrm{f}}$ & $1.06^{\mathrm{c}-\mathrm{e}}$ & $0.955^{\mathrm{a}}$ & $2.34^{\mathrm{ef}}$ & $4.84^{\mathrm{de}}$ & $0.143^{\mathrm{b}-\mathrm{d}}$ & $0.190^{\mathrm{d}-\mathrm{f}}$ \\
\hline QUE20 & $0.085^{\mathrm{a}-\mathrm{d}}$ & 0.305 & $0.489^{b-f}$ & $1.13^{\mathrm{a}-\mathrm{c}}$ & $0.851^{\mathrm{i}}$ & $2.63^{b-d}$ & $5.13^{\mathrm{b}-\mathrm{d}}$ & $0.101^{\mathrm{de}}$ & $0.164^{\mathrm{fg}}$ \\
\hline QUE40 & $0.093^{\mathrm{a}-\mathrm{c}}$ & 0.320 & $0.519^{\mathrm{a}-\mathrm{d}}$ & $1.18^{\mathrm{a}}$ & $0.862^{\text {hi }}$ & $2.71^{\mathrm{ab}}$ & $5.24^{\mathrm{a}-\mathrm{c}}$ & $0.103^{\mathrm{de}}$ & $0.166^{\mathrm{e}-\mathrm{g}}$ \\
\hline QUE60 & $0.084^{\mathrm{a}-\mathrm{d}}$ & 0.273 & $0.491^{b-f}$ & $1.07^{\mathrm{c}-\mathrm{e}}$ & $0.881^{\mathrm{fg}}$ & $2.59^{\mathrm{b}-\mathrm{f}}$ & $5.06^{\mathrm{b}-\mathrm{e}}$ & $0.096^{\mathrm{e}}$ & $0.134^{\mathrm{g}}$ \\
\hline QUE80 & $0.071^{\mathrm{de}}$ & 0.251 & $0.436^{\mathrm{ef}}$ & $1.04^{\mathrm{e}}$ & $0.947^{\mathrm{ab}}$ & $2.32^{\mathrm{f}}$ & $4.79^{\mathrm{e}}$ & $0.112^{\mathrm{de}}$ & $0.188^{\mathrm{d}-\mathrm{f}}$ \\
\hline GRA20 & $0.077^{\mathrm{de}}$ & 0.309 & $0.535^{\mathrm{a}-\mathrm{c}}$ & $1.09^{\mathrm{b}-\mathrm{e}}$ & $0.884^{\mathrm{fg}}$ & $2.73^{\mathrm{ab}}$ & $5.28^{\mathrm{ab}}$ & $0.143^{\mathrm{b}-\mathrm{d}}$ & $0.203^{\mathrm{c}-\mathrm{e}}$ \\
\hline GRA40 & $0.075^{\mathrm{de}}$ & 0.287 & $0.502^{\mathrm{a}-\mathrm{f}}$ & $1.07^{\mathrm{c}-\mathrm{e}}$ & $0.878^{\mathrm{t}-\mathrm{h}}$ & $2.61^{\mathrm{b}-\mathrm{e}}$ & $5.09^{\mathrm{b}-\mathrm{e}}$ & $0.194^{\mathrm{a}}$ & $0.222^{\mathrm{cd}}$ \\
\hline GRA60 & $0.075^{\mathrm{de}}$ & 0.289 & $0.528^{\mathrm{a}-\mathrm{d}}$ & $1.07^{\mathrm{c}-\mathrm{e}}$ & $0.890^{\mathrm{ef}}$ & $2.62^{\mathrm{b}-\mathrm{e}}$ & $5.12^{\mathrm{b}-\mathrm{d}}$ & $0.189^{\mathrm{a}}$ & $0.231^{\mathrm{bc}}$ \\
\hline GRA80 & $0.079^{\mathrm{c}-\mathrm{e}}$ & 0.289 & $0.540^{\mathrm{a}-\mathrm{c}}$ & $1.09^{\mathrm{b}-\mathrm{e}}$ & $0.922^{\mathrm{cd}}$ & $2.64^{\mathrm{bc}}$ & $5.16^{\mathrm{b}-\mathrm{d}}$ & $0.175^{\mathrm{ab}}$ & $0.231^{\mathrm{bc}}$ \\
\hline CHE20 & $0.095^{\mathrm{ab}}$ & 0.316 & $0.521^{\mathrm{a}-\mathrm{d}}$ & $1.17^{\mathrm{a}}$ & $0.871^{\mathrm{gh}}$ & $2.68^{b c}$ & $5.21^{\mathrm{a}-\mathrm{c}}$ & $0.134^{\mathrm{b}-\mathrm{e}}$ & $0.221^{\mathrm{cd}}$ \\
\hline CHE40 & $0.096^{\mathrm{ab}}$ & 0.318 & $0.513^{\mathrm{a}-\mathrm{e}}$ & $1.16^{\mathrm{ab}}$ & $0.876^{\mathrm{f}-\mathrm{h}}$ & $2.64^{b c}$ & $5.19^{a-c}$ & $0.123^{\mathrm{c}-\mathrm{e}}$ & $0.262^{\mathrm{ab}}$ \\
\hline CHE60 & $0.098^{\mathrm{ab}}$ & 0.312 & $0.550^{\mathrm{ab}}$ & $1.11^{\mathrm{a}-\mathrm{e}}$ & $0.894^{\text {ef }}$ & $2.77^{\mathrm{ab}}$ & $5.29^{\mathrm{ab}}$ & $0.104^{\mathrm{de}}$ & $0.147^{\mathrm{g}}$ \\
\hline CHE80 & $0.074^{\mathrm{de}}$ & 0.255 & $0.455^{\mathrm{d}-\mathrm{f}}$ & $1.06^{\mathrm{de}}$ & $0.934^{\mathrm{bc}}$ & $2.36^{\mathrm{d}-\mathrm{f}}$ & $4.84^{\mathrm{de}}$ & $0.137^{\mathrm{b}-\mathrm{e}}$ & $0.200^{\mathrm{c}-\mathrm{f}}$ \\
\hline OAK20 & $0.099^{\mathrm{a}}$ & 0.352 & $0.578^{\mathrm{a}}$ & $1.13^{\mathrm{a}-\mathrm{d}}$ & $0.876^{\mathrm{f}-\mathrm{h}}$ & $2.96^{\mathrm{a}}$ & $5.49^{\mathrm{a}}$ & $0.172^{\mathrm{a}-\mathrm{c}}$ & $0.294^{\mathrm{a}}$ \\
\hline OAK40 & $0.084^{b-d}$ & 0.310 & $0.505^{\mathrm{a}-\mathrm{f}}$ & $1.07^{\mathrm{c}-\mathrm{e}}$ & $0.882^{\text {fg }}$ & $2.69^{\mathrm{a}-\mathrm{c}}$ & $5.21^{\mathrm{a}-\mathrm{c}}$ & $0.178^{\mathrm{ab}}$ & $0.272^{\mathrm{a}}$ \\
\hline OAK60 & $0.077^{\mathrm{de}}$ & 0.304 & $0.519^{\mathrm{a}-\mathrm{d}}$ & $1.07^{\mathrm{c}-\mathrm{e}}$ & $0.907^{\mathrm{de}}$ & $2.67^{\mathrm{bc}}$ & $5.19^{a-c}$ & $0.160^{\mathrm{a}-\mathrm{c}}$ & $0.199^{c-f}$ \\
\hline OAK80 & $0.074^{\mathrm{de}}$ & 0.264 & $0.470^{\mathrm{c}-\mathrm{f}}$ & $1.09^{c-e}$ & $0.957^{\mathrm{a}}$ & $2.41^{\mathrm{c}-\mathrm{f}}$ & $4.94^{\mathrm{c}-\mathrm{e}}$ & $0.144^{\mathrm{b}-\mathrm{d}}$ & $0.200^{\mathrm{c}-\mathrm{f}}$ \\
\hline $\mathrm{SED}^{4}$ & 0.0073 & 0.0336 & 0.0379 & 0.0372 & 0.0091 & 0.137 & 0.159 & 0.0243 & 0.0158 \\
\hline P-value & 0.004 & 0.232 & 0.027 & 0.007 & $<0.001$ & 0.003 & 0.010 & $<0.001$ & $<0.001$ \\
\hline \multicolumn{10}{|c|}{ Contrasts ${ }^{5}$} \\
\hline QUE & LQ & & & $Q$ & LQC & & & $\mathrm{L}$ & $\mathrm{L}$ \\
\hline
\end{tabular}




\begin{tabular}{llcccccc}
\hline GRA & & & LQ & Q & & \\
CHE & LQ & L & Q & LQC & L & L & L \\
OAK & LQ & QC & & LQ & QC & Q & QC \\
\hline
\end{tabular}

${ }^{1}$ The incubated substrate was a TMR (forage:concentrate ratio 50:50) supplemented with $20 \mathrm{~g}$ of sunflower oil/kg diet DM.

${ }^{2} \mathrm{BCFA}$, branched-chain fatty acids.

${ }^{3}$ OBCFA, odd- and branched-chain fatty acids.

${ }^{4} \mathrm{SED}=$ standard error of the difference.

${ }^{5}$ For each tannin, significance of linear (L), quadratic (Q) and cubic (C) responses to tannin addition.

${ }^{\mathrm{a}-\mathrm{i}}$ Within a column, different superscripts indicate significant differences. 


\section{Table 4}

Effect of the addition of an oak tannin extract $(20 \mathrm{~g} / \mathrm{kg}$ diet DM) on rumen fermentation parameters after in vitro incubation with rumen inoculum from sheep ${ }^{1}$.

\begin{tabular}{lcccc}
\hline Item $^{2}$ & Control & OAK20 & SED $^{3}$ & P-value \\
\hline $\mathrm{DMD}_{72}(\mathrm{~g} / \mathrm{g})$ & 0.703 & 0.679 & 0.0301 & 0.464 \\
$A(\mathrm{~mL} / \mathrm{g} \mathrm{OM})$ & 381 & 381 & 10.7 & 0.979 \\
$c(/ \mathrm{h})$ & 0.068 & 0.071 & 0.0016 & 0.176 \\
$\mathrm{AFR}$ & 18.7 & 19.5 & 0.355 & 0.115 \\
$\mathrm{ED}(\mathrm{g} / \mathrm{g})$ & 0.435 & 0.426 & 0.0209 & 0.690 \\
$i v \mathrm{TSD}(\mathrm{g} / \mathrm{g})$ & 0.809 & 0.802 & 0.0195 & 0.752 \\
$\mathrm{pH}$ & 6.44 & 6.46 & 0.0240 & 0.526 \\
Ammonia $(\mathrm{mg} / \mathrm{L})$ & 709 & 654 & 101 & 0.618 \\
Total VFA (mmol/L) & 79.2 & 71.5 & 4.72 & 0.176 \\
Molar proportions (mol/mol) & & & & \\
$\quad$ Acetate & 0.613 & 0.602 & 0.0225 & 0.641 \\
$\quad$ Propionate & 0.177 & 0.182 & 0.0117 & 0.664 \\
$\quad$ Butyrate & 0.157 & 0.162 & 0.0095 & 0.665 \\
$\quad$ Others & 0.053 & 0.054 & 0.0029 & 0.671 \\
Acetate:propionate ratio & 3.52 & 3.35 & 0.338 & 0.635 \\
\hline
\end{tabular}

${ }^{1}$ The incubated substrate was a TMR (forage:concentrate ratio 50:50) supplemented with $20 \mathrm{~g}$ of sunflower oil/kg diet DM.

${ }^{2} A=$ cumulative gas production; AFR $=$ average fermentation rate; $c=$ fractional fermentation rate; $\mathrm{DMD}_{72}=\mathrm{DM}$ disappearance after $72 \mathrm{~h}$ of incubation; $\mathrm{ED}=$ extent of degradation in the rumen; $i v \mathrm{TSD}=$ in vitro true substrate digestibility; $\mathrm{VFA}=$ volatile fatty acids.

${ }^{3} \mathrm{SED}=$ standard error of the difference.

${ }^{4}$ Calculated as the sum of isobutyrate, isovalerate and valerate. 


\section{Table 5}

Effect of the addition of an oak tannin extract $(20 \mathrm{~g} / \mathrm{kg}$ diet DM) on the diversity indices of the bacterial community, and on the relative frequencies [expressed as $\log _{10}(n+c)$ of the percentage over the total peak area, with original values in parentheses] of some terminal restriction fragments $(\mathrm{T}-\mathrm{RF})$ after $24-\mathrm{h}$ in vitro incubation with rumen inoculum from sheep ${ }^{1}$.

\begin{tabular}{|c|c|c|c|c|c|}
\hline & & Control & OAK20 & $\mathrm{SED}^{2}$ & P-value \\
\hline \multicolumn{6}{|l|}{ Diversity indices } \\
\hline HhaI & $\begin{array}{l}\text { Richness } \\
\text { Shannon index }\end{array}$ & $\begin{array}{l}64.3 \\
3.58\end{array}$ & $\begin{array}{l}63.0 \\
3.59\end{array}$ & $\begin{array}{c}2.67 \\
0.0658\end{array}$ & $\begin{array}{l}0.643 \\
0.933\end{array}$ \\
\hline MspI & $\begin{array}{l}\text { Richness } \\
\text { Shannon index }\end{array}$ & $\begin{array}{l}95.0 \\
4.11\end{array}$ & $\begin{array}{l}95.3 \\
4.15\end{array}$ & $\begin{array}{c}4.70 \\
0.0509\end{array}$ & $\begin{array}{l}0.947 \\
0.472\end{array}$ \\
\hline HaeIII & $\begin{array}{l}\text { Richness } \\
\text { Shannon index }\end{array}$ & $\begin{array}{l}56.0 \\
3.61\end{array}$ & $\begin{array}{l}57.3 \\
3.62\end{array}$ & $\begin{array}{c}3.67 \\
0.0732\end{array}$ & $\begin{array}{l}0.735 \\
0.940\end{array}$ \\
\hline \multicolumn{6}{|l|}{$\mathrm{T}$-RF frequencies } \\
\hline Clostridia $^{3}$ & $\begin{array}{l}750 \text { bp (HhaI) } \\
95 \text { bp (MspI) }\end{array}$ & $\begin{array}{c}-0.064 \\
(0.864) \\
0.836 \\
(7.06)\end{array}$ & $\begin{array}{l}0.099 \\
(1.28) \\
0.836 \\
(7.42)\end{array}$ & 0.0611 & 0.056 \\
\hline \multirow[t]{3}{*}{ Lachnospiraceae ${ }^{3}$} & $65 \mathrm{bp}(\mathrm{Hhal})$ & $\begin{array}{l}0.895 \\
(7.87)\end{array}$ & $\begin{array}{l}0.946 \\
(8.82)\end{array}$ & 0.0138 & 0.022 \\
\hline & 293 bp (MspI) & $\begin{array}{l}0.077 \\
(1.20)\end{array}$ & $\begin{array}{l}0.176 \\
(1.50)\end{array}$ & 0.0247 & 0.016 \\
\hline & 277 bp (HaeIII) & $\begin{array}{l}-0.056 \\
(0.227)\end{array}$ & $\begin{array}{l}0.291 \\
(1.28)\end{array}$ & 0.109 & 0.034 \\
\hline
\end{tabular}

${ }^{1}$ The incubated substrate was a TMR (forage:concentrate ratio 50:50) supplemented with $20 \mathrm{~g}$ of sunflower oil/kg diet DM.

${ }^{2} \mathrm{SED}=$ standard error of the difference.

${ }^{3}$ Putative taxonomic identification. 


\section{FIGURE CAPTIONS}

Figure 1. Effect of incremental levels of different tannin extracts (quebracho, grape, chestnut and oak) on the percentage of variation with respect to the control (i.e., without tannins) of 17:0 (SEM=0.801), 18:0 (SEM=0.317), cis-9 18:1 (SEM=1.45), trans-10 18:1 (SEM=1.82), trans-11 18:1 (SEM=0.987), cis-9 trans-11 18:2 (SEM=10.5), 18:2n$6(\mathrm{SEM}=5.32)$, and 18:3n-3 (SEM=6.09) content after 12-h in vitro incubation with rumen inoculum from sheep.

Differences $(*: \mathrm{P}<0.05 ; \mathrm{t}: \mathrm{P}<0.10)$ compared with the control. SEM=standard error of the mean. 
FIGURE 1
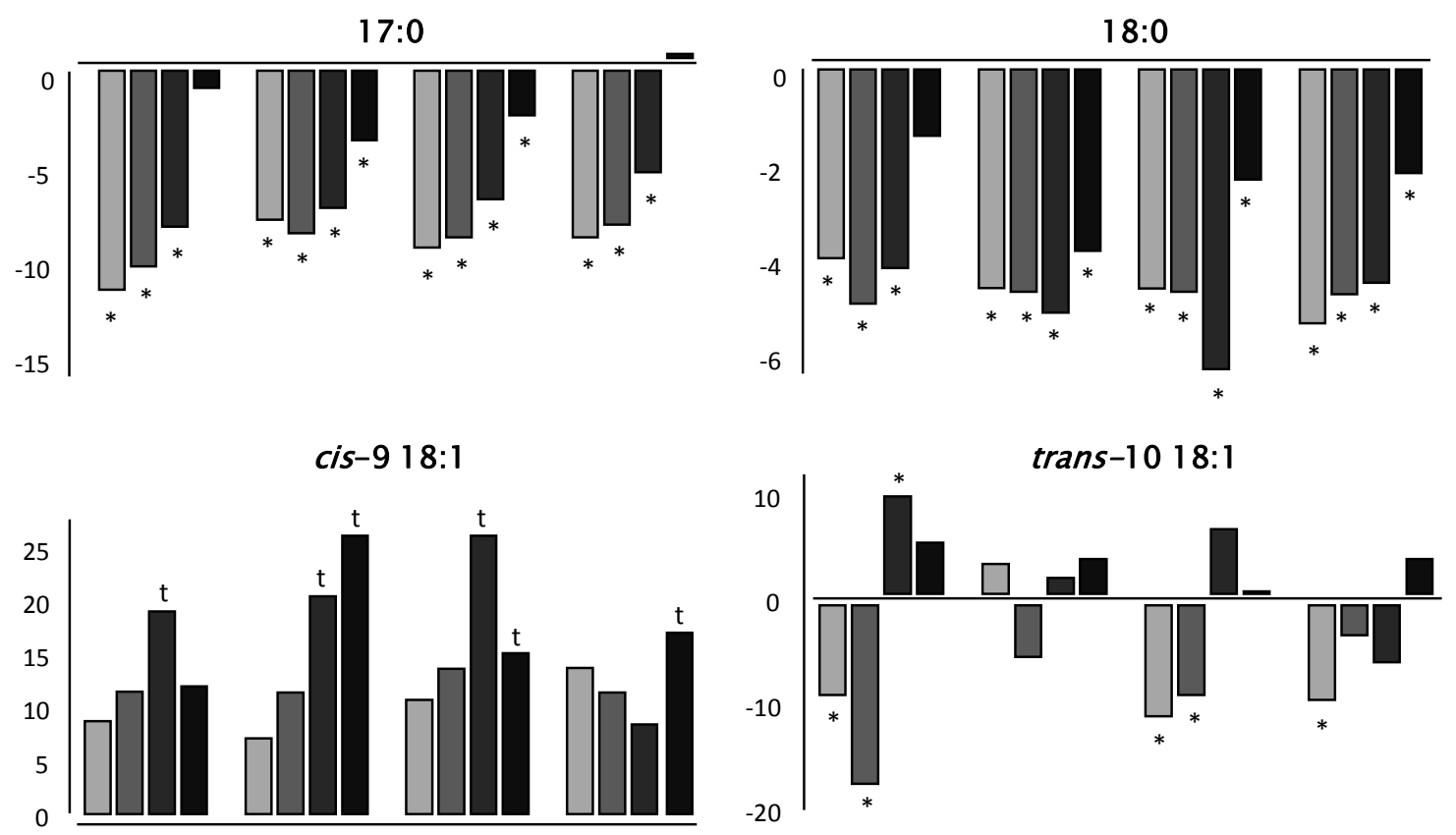

trans-11 18:1

cis-9 trans-11 18:2
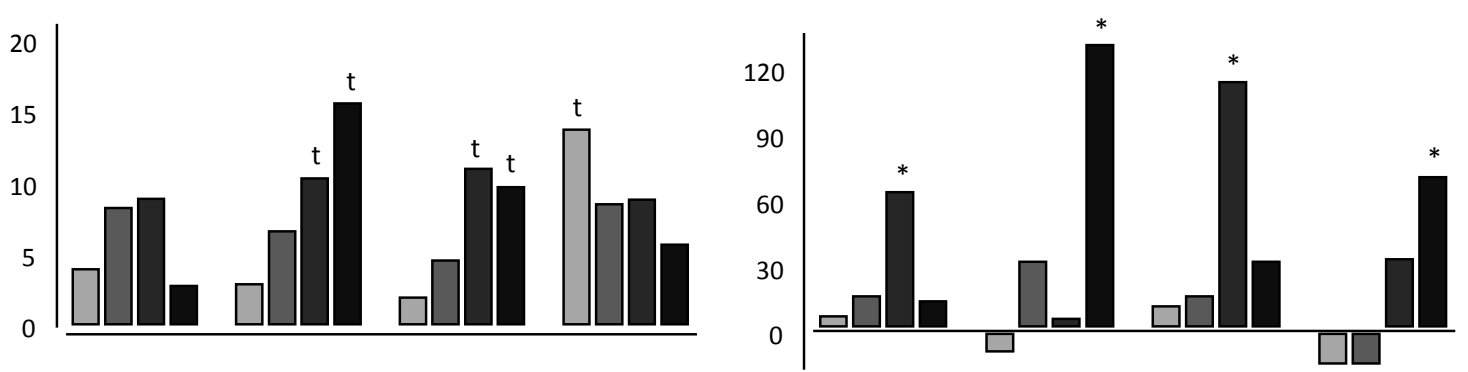

$18: 2 n-6$
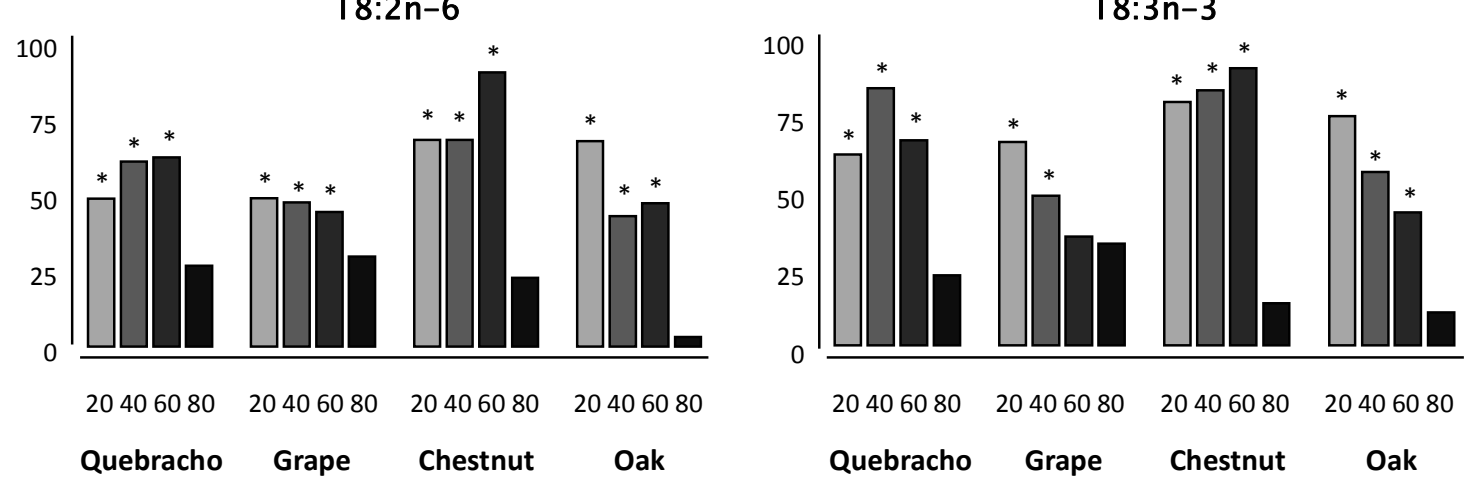